\title{
FASTEN: An loT platform for Supply Chain Management in a Covid-19 Pandemic Scenario
}

\author{
Fernando Lemos \\ PUCRS
}

Thays do Nascimento

PUCRS

Gustavo Dalmarco

INESC TEC - Institute for Systems and Computer Engineering, Technology and Science

Follow this and additional works at: https://digitalcommons.uri.edu/mgdr

Part of the Business Administration, Management, and Operations Commons, Computer and Systems Architecture Commons, Economics Commons, Industrial Engineering Commons, Marketing Commons, Operational Research Commons, Robotics Commons, and the Systems Engineering Commons

\section{Recommended Citation}

Lemos, Fernando; do Nascimento, Thays; and Dalmarco, Gustavo (2020) "FASTEN: An loT platform for Supply Chain Management in a Covid-19 Pandemic Scenario," Markets, Globalization \& Development Review: Vol. 5: No. 4, Article 2.

DOI: 10.23860/MGDR-2020-05-04-02

Available at: https://digitalcommons.uri.edu/mgdr/vol5/iss4/2

This Article is brought to you for free and open access by DigitalCommons@URI. It has been accepted for inclusion in Markets, Globalization \& Development Review by an authorized editor of DigitalCommons@URI. For more information, please contact digitalcommons-group@uri.edu. 
FASTEN: An loT platform for Supply Chain Management in a Covid-19 Pandemic Scenario

\section{Cover Page Footnote}

This work has received funding from the European Union's Horizon 2020 research and innovation program under the Grant Agreement No 777096 and from SEPIN/MCTI under the 4th Coordinated Call BR-EU in CIT. 


\section{Markets, Globalization \& Development Review}
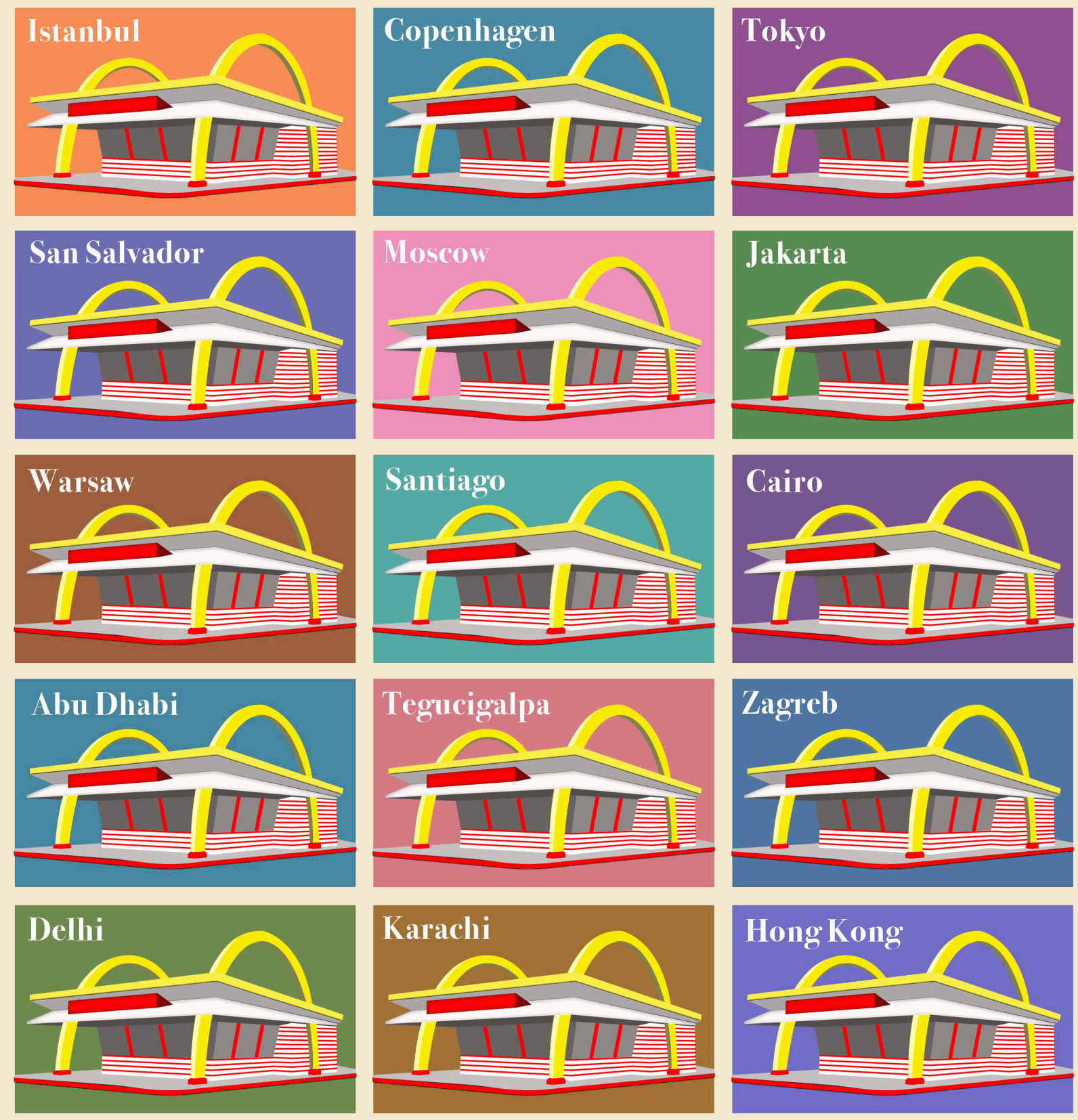

This article is available in Markets, Globalization \& Development Review: https://digitalcommons.uri.edu/mgdr/vol5/ 


\section{FASTEN: An IoT Platform for Supply Chain Management in a Covid-19 Pandemic Scenario}

\section{Introduction}

Responsiveness, reliability and resilience in Production Systems and Supply Chains are measured by the system's ability to respond and adapt quickly to failure events, maintaining a high level of service as well as dealing with product mix variations and uncertainties in quantities demanded by customers. In the Pandemic Rupture Scenario of COVID19 , where manufacturing and transportation get very constrained, there is an increasing demand for Production Systems to be adaptable to the dynamic changes in the market, producing what is needed in the quantity, at the moment, and often at the place demanded. This requires new business models and changes in management practices, physical infrastructure, manufacturing operations, technologies, and skills and abilities of human resources. This scenario enhances the development and application of Industry 4.0 tools and concepts (Davis et al. 2012; Ghobakhloo 2018). To familiarize the readers, Table 1 outlines the key characteristics of the Industry 1.0 to Industry 4.0 evolutionary generations. Also, to aid the readers, Table 2 lists most of the abbreviations used and their expansions.

Table 1: Evolving Generations of Industry Tools and Concepts

\begin{tabular}{|c|c|c|}
\hline Generation & $\begin{array}{l}\text { Key Characteristics and Features, in } \\
\text { Brief Form }\end{array}$ & $\begin{array}{l}\text { Additional } \\
\text { Comments }\end{array}$ \\
\hline Industry 1.0 & $\begin{array}{l}\text { The Industry 1.0, which occurred at } \\
\text { the end of seventeenth century, } \\
\text { came with introducing machines into } \\
\text { production. Steam-powered engines } \\
\text { and mechanization replaced the } \\
\text { manual production system and water } \\
\text { is being used as a source of power. }\end{array}$ & $\begin{array}{lr}\text { Transition } & \text { from } \\
\text { agriculture } & \text { to } \\
\text { industrial society. }\end{array}$ \\
\hline Industry 2.0 & $\begin{array}{l}\text { The Industry } 2.0 \text { dates near } 1870 \text {. } \\
\text { Development of electrical technology } \\
\text { which was technologically superior to } \\
\text { steam power for the production } \\
\text { works. Technological advancements } \\
\text { facilitated the development of heavy }\end{array}$ & $\begin{array}{l}\text { In this way the } \\
\text { concept of mass } \\
\text { production came } \\
\text { to the public } \\
\text { domain. It was } \\
\text { driven by the }\end{array}$ \\
\hline
\end{tabular}




\begin{tabular}{|c|c|c|}
\hline & industries. & assembly lines. \\
\hline Industry 3.0 & $\begin{array}{l}\text { The third industrial revolution } \\
\text { appears around the second half of } \\
\text { the 20th century. It is often referred to } \\
\text { as the Digital Revolution and came } \\
\text { about the change from analog and } \\
\text { mechanical systems to digital ones in } \\
\text { manufacturing processes. This time } \\
\text { is also being called as Information } \\
\text { Age. }\end{array}$ & $\begin{array}{l}\text { It was possible } \\
\text { due to the huge } \\
\text { development in } \\
\text { computers, } \\
\text { information, } \\
\text { communication, } \\
\text { and automation } \\
\text { technology. }\end{array}$ \\
\hline Industry 4.0 & $\begin{array}{l}\text { Industry } 4.0 \text { visualizes a complete } \\
\text { automated manufacturing and } \\
\text { production system with total } \\
\text { adaptability. CPS, loT, M2M } \\
\text { communication and autonomy come } \\
\text { together and brings about more } \\
\text { consistent, robust, agile } \\
\text { manufacturing systems with } \\
\text { intelligent capabilities. } \\
\text { Internet of Things (loT) allows the } \\
\text { machines to communicate (M2M). } \\
\text { Cyber physical systems (CPS) are } \\
\text { core elements of this transformation. } \\
\text { These technological advancements } \\
\text { become possible with the introduction } \\
\text { of self-optimization, self- } \\
\text { customization, and self-cognition } \\
\text { techniques into the industries. }\end{array}$ & 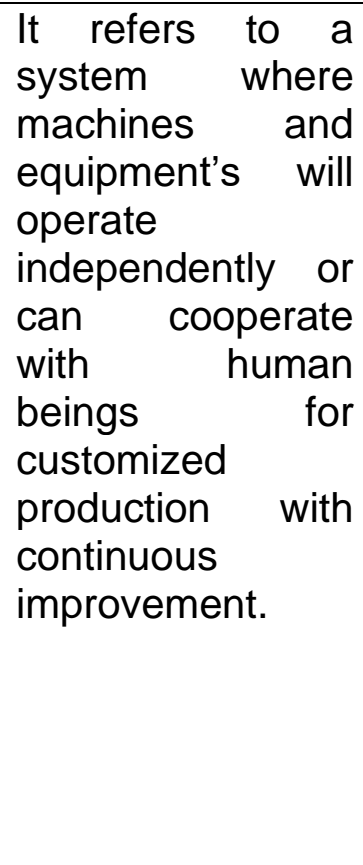 \\
\hline
\end{tabular}

Source: Ghobakhloo 2018; Kumar and Kumar 2020; Oztemel and Gursev 2020.

Table 2: Technical Abbreviations and Their Expansions

\begin{tabular}{|l|l|}
\hline Abbreviation & Expansion (Explanation, if needed) \\
\hline AM & Additive Manufacturing \\
\hline APM & $\begin{array}{l}\text { Advanced Plant Model, who is } \\
\text { responsible for allocating the } \\
\text { manufacturing order to the specific 3D } \\
\text { printer and to the robot, after the part is } \\
\text { printed. }\end{array}$ \\
\hline
\end{tabular}




\begin{tabular}{|l|l|}
\hline CPS & Cyber Physical Systems \\
\hline ERP & Enterprise Resource Planning \\
\hline FASTEN & $\begin{array}{l}\text { Flexible and Autonomous } \\
\text { Manufacturing Systems for Custom- } \\
\text { Designed Products, FASTEN aims to } \\
\text { develop an open and standardized } \\
\text { framework to produce and deliver tailor- } \\
\text { designed products, capable to run } \\
\text { autonomously, and deliver fast and low } \\
\text { cost additive manufactured products. }\end{array}$ \\
\hline IOT & Internet of Things \\
\hline M2M & Machines to communicate \\
\hline SRAM & $\begin{array}{l}\text { Smart Robotic Additive Manufacturing, } \\
\text { The SRAM is composed of a 3D printer } \\
\text { manufacturing cell supported by robots } \\
\text { running autonomously, monitored and } \\
\text { driven by FASTEN loT Platform (WP3), } \\
\text { and supported by predictive tools. }\end{array}$ \\
\hline SC & Supply Chain \\
\hline SMS & Smart Manufacturing Systems \\
\hline RAMI 4.0 & $\begin{array}{l}\text { Reference Architectural Model of } \\
\text { Industry 4.0 }\end{array}$ \\
\hline
\end{tabular}

Source: Authors' summarizing.

The Industry 4.0 evolution is currently underway, shaping a future that will rely heavily on data acquisition and sharing throughout Supply Chains (Barata, Cunha and Stal 2018; European Comission 2016; Brettel et al. 2014). This vision of interconnected business services, processes, and information systems is only possible due to technological developments in Cyber Physical Systems (Dalmarco et al. 2019). Industry 4.0 is related to what is called the "smart factory" (Evans and Annunziata 2012) where the decision process is decentralized (Bonomi et al. 2012) and supported by a range of technologies of Smart Manufacturing Systems including Internet of Things (IOT), Additive Manufacturing (AM), Big Data and Cloud Computing; and also by design and production principles such as Mass Customization, Virtualization, Modularization and Sustainable Manufacturing) (Ghobakhloo 2018; La Mora 2014; Lin et al. 2018).

A Smart Manufacturing Systems (SMS) is the focus of development of the FASTEN project: Flexible and Autonomous Manufacturing Systems for Custom-Designed Products. FASTEN - an abbreviation of the 
Portuguese language phrase - aims to develop, demonstrate, validate, and disseminate an integrated and modular structure for an efficient production of highly customized products, based on real-time connection between demanding systems and supplier systems. An loT platform, based on the open architecture RAMI 4.0 (Reference Architectural Model of Industry 4.0), is under development to operationalize information and material flows in an autonomous and optimized way (Reis et al. 2018).

This paper deals with the analysis of how FASTEN platform can be used in a Covid-19 pandemic scenario in Brazil. For this reason, our analysis will describe the development of a supply chain for production of face shields through 3D printing technologies.

In Brazil, industry is moving from standard assembly lines to high-level automation (Leung et al. 2015). The National Confederation of Industry (abbreviated CNI, in Portuguese) argues that the advance of Industry 4.0 in Brazil will rely heavily on knowledge and digitization - that is, use of digital information, from multiple sources, formats or systems, to implement improvements in the manufacturing process, supply chain, products or services (Büyüközkan and Göçer 2018; Brecher et al. 2017; Porter and Heppelmann 2015) - as means of improving productivity, flexibility, reducing time-to-market and opening new business models opportunities. The use of Industry 4.0 allows the development of customized products at competitive prices and managing of production complexities that were once a barrier. Here the use of loT technologies is the base of Industry 4.0, as it makes use of the increasing availability of communication infrastructure to form large networks, connecting the most diverse types of equipment (Leung et al. 2015). Here, loT technologies refer to the interconnection of sensing and actuating devices, thereby providing the ability to share information across platforms through a unified framework, developing a common operating picture for enabling innovative applications (Gubbi et al. 2013). In this scenario, it is necessary to establish in Brazil, a long-term vision in line with the opportunities derived from Industry 4.0 technologies (Osakwe, Chovancová and Agu 2016).

\section{Supply Chain Disruption}

Supply chains (SC) operate in environments of uncertainty, with variability in demand, production and supply, directing the choice of models that represent the stochasticity of demand, production and supply (Sabri and Beamon 2000). The potential failure events in SC, and variations and uncertainties of the mix and quantities of products demanded by customers, direct the process of identification and risk management in a 
SC (Thun and Hoenig 2011). Risk in SC is understood to mean events with a low probability of occurrence that occur abruptly and that result in negative consequences for the analyzed system. These events refer to failures in the processes of supply, production or delivery of the component companies of a SC (Tang 2006; Tang and Musa 2011).

SC disruption risk (SCDR) is defined as a combination of events and/or anomalous and unintended conditioning factors that threaten the normal operations of a SC and which cannot usually be predicted (Sheffi and Rice 2005; Wagner and Bode 2008). Garcia-Herreros et al. (2014) point out that the SCDR are often neglected in the risk analysis, due to the unpredictability of the occurrence. Under the COVID-19 pandemic conditions, SCDR became pervasive in many industries.

In SC rupture scenarios, strategies should be directed to the agility/speed, collaboration/visibility and/or flexibility to recover the SC after the risk event has occurred. The implementation of these strategies also requires a trade-off analysis between robustness or resilience of SC and the efficiency and effectiveness of SC in a normal operating situation (Hohenstein et al. 2015; Kleindorfer and Saad 2005). The resilience of SC is measured by its ability to respond and adapt quickly to production process, demand and supply failures, irregularities and uncertainties in the mix of products and quantities demanded, and quality problems of delivered products (Thun and Hoenig 2011; Ponomarov and Holcomb 2009; Tang 2006). The robustness of SC is characterized by the support of the activities and operational and logistic structures of the same in scenarios of risks of failures or irregularities in the productive and logistic processes, being able to be measured by the capacity to maintain the performance during and after a failure event and/or irregularities (Tang 2006).

It is essential, in order to sustain the competitiveness of SC, to create resilience and/or robustness, i.e. to develop the system's ability to return to its normal state of functioning or to a desired state after a disturbance and/or size and position reserves and redundancies in SC (Carvalho, Azevedo and Cruz-Machado 2012; Chopra and Sodhi 2004).

The Covid-19 epidemic caused an unexpected demand for the provision of hospital safety items, such as face shields. Supply chain vulnerabilities were exposed by supply failures, requiring actions to implement robustness and/or resilience in SC. This required the organization of new supply chains and a structured and effective management with support systems, such as SMS, to guarantee the continuity of operations and the coordination and collaboration between the participants of a SC. 


\section{FASTEN - A Smart Manufacturing System Project}

SMS allow to improve production efficiency in scenarios of constant changes in product requirements and production volume. One of the benefits of an SMS is to enhance the implementation of mass customization, through the digitalization process of product lifecycle management and the implementation of flexible processes of planning, scheduling and production optimization to meet the high variety of products (Lasi et al. 2014). SMS seek to develop competitive priorities, such as flexibility, delivery, quality and costs, through the use of cloud computing, autonomous robots, internet of things (IoT), Digital Manufacturing, Additive Manufacturing (AM), systems of distributed manufacturing and production management and control software (Davis et al. 2012; Rübmann et al. 2015). Similarly, in this volume of MGDR, Vicdan (2020) discussed how during times of crisis in health care, "platform organizations bring together diverse market actors for partnership for the creation and distribution of aggregate patient data, on which the market can act and deliver outcomes that are potentially beneficial for the parties involved (p.1),"

Through AM companies seek to improve performance and quality of products, cost efficiency, reduction of waste of materials, reduction of energy consumption and reduction of operation times, that is, eliminating and / or minimizing existing design and production restrictions in traditional materials synthesis techniques. AM allows the printing of complex geometries with control of composition, microstructure and, consequently, of the functionalities of the materials, optimizing the properties of the items produced (Huang et al. 2015; Jared et al. 2017).

The FASTEN project adds the concept of decentralized manufacturing supported by a SMS, developing an open and standardized structure to produce and deliver custom demands. The FASTEN platform will allow the structuring, management and operation of a network of heterogeneous AM cells. Each cell is called an SRAM production unit (Smart Robotic Additive Manufacturing).

In a country as big as Brazil, a centralized manufacturing unit has a big effort in logistics, as it needs to send products and spare parts to distant locations. FASTEN will apply the decentralized manufacturing concept to improve the service level in meeting customized demands. SRAM units will improve this concept, being capable of operating autonomously and delivering one-of-a-kind parts produced close to the client. The network will be managed by decentralizing decision-making and data exchange tools, using technologies for self-learning, selfoptimization and advanced control. FASTEN will provide operational 
convenience by promoting the transition from current manufacturing systems to new patterns of decentralized manufacturing in a viable manner, both in terms of economic performance and long-term sustainability.

The use of a decentralized manufacturing network reduces logistics costs and production lead-time, as products and spare parts can be manufactured close to the client. The use of AM technologies adds flexibility and autonomy to the manufacturing unit, improving production schedule efficiency. With the introduction of 3D printing (and other) technologies, incorporated into a flexible manufacturing system that is embedded in an Industrial loT Cloud Platform (proposed as FASTEN IoT Platform), the SC would see several benefits when operating:

- $\quad$ Parts would be manufactured faster, as there is no need for long machine/line setup;

- With a flexible, self-adaptable system capable of one-of-akind production, producing a single or multiple piece (in small batches) would not affect system performance; and

- $\quad$ Customer services and satisfaction would be significantly improved, with immediate availability of replacement parts, even for outdated models.

The FASTEN IoT Platform - based on FIWARE open-source platform - is able to interconnect a range of different components (Figure 1) to the company's Enterprise Resource Planning (ERP) software. For FASTEN Industrial testing, the ERP was used to manage all production orders that were sent to the different SRAMs, including current production jobs running, jobs in error status and manufacture queue. 
Figure 1 - FASTEN Components

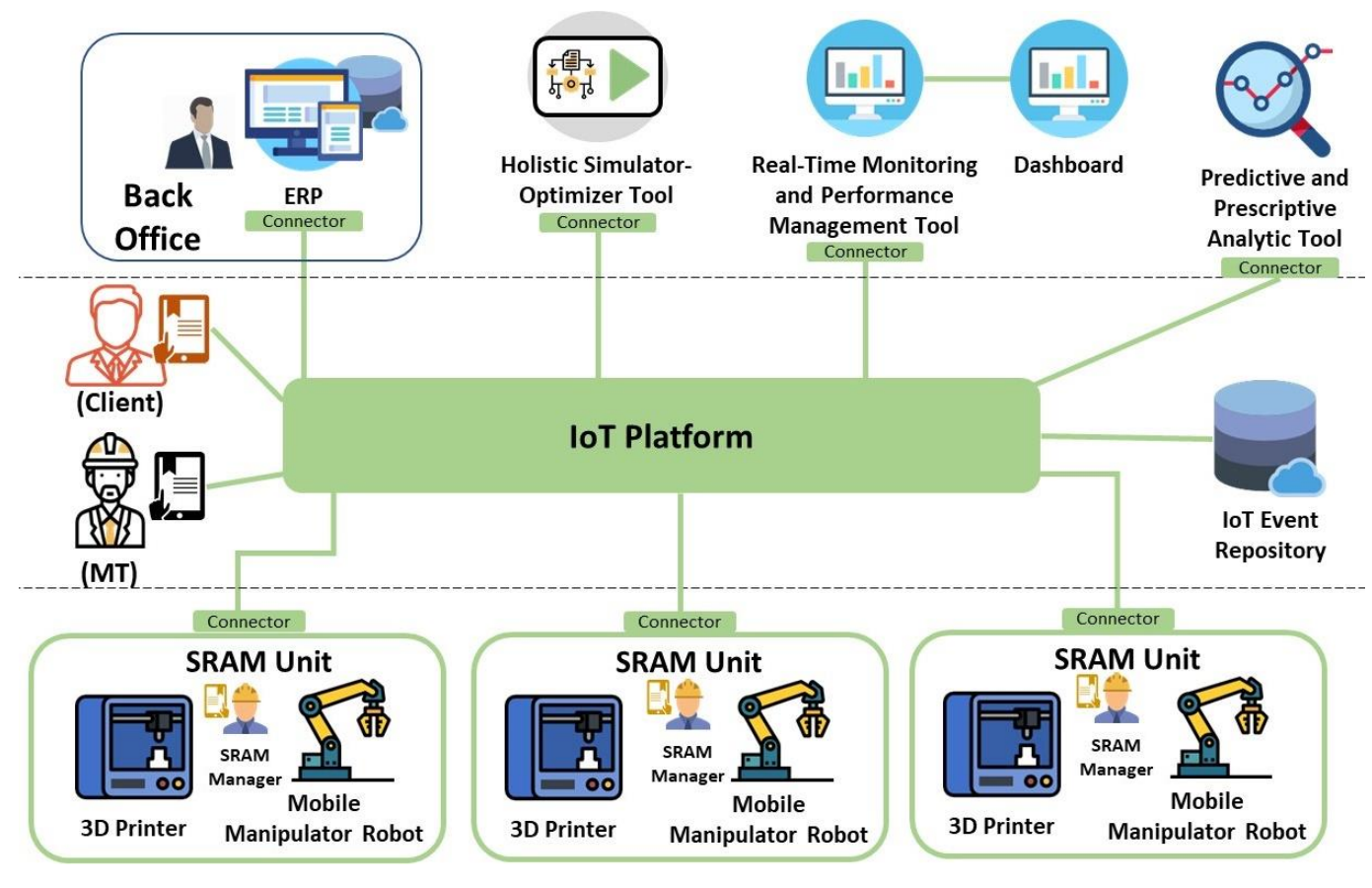

Source: the authors

Between the functionalities provided to the focal company ERP the other FASTEN components that can be accessed are described below:

- $\quad$ SRAM Unit: Where the parts will be printed, the units are equipped with 3D printers;

- Advanced Plant Model (APM): It is a virtual representation of the SRAM unit.

- Holistic Simulator-Optimizer Tool: Used to arrange an optimal SRAM Network and, during production scheduling, to define the optimal SRAM to produce a certain part;

- Real-time Monitoring and Performance Management Tool: This software component will display in a dashboard real-time information about the activities being accomplished in the SRAM unit by the 3D Printer and present performance indicators;

- $\quad$ Predictive and Prescriptive Analytic Tool: Responsible for analyzing data and predict demands;

- $\quad$ IoT Event Repository: Responsible for storing all data from sensors and manufacturing orders. 
In order to operationalize the developments of FASTEN, a functional test platform was developed encompassing two SRAMs located in different cities in Brazil - one in Porto Alegre (RS), other in Salvador (BA). The operationalization of the FASTEN IOT Platform starts by the configuration of a SRAM Network (Figure 2), which demonstrates the use of the Predictive and Prescriptive Analytic Tool on a strategic level.

Figure 2 - Smart Manufacturing Network Configuration Process

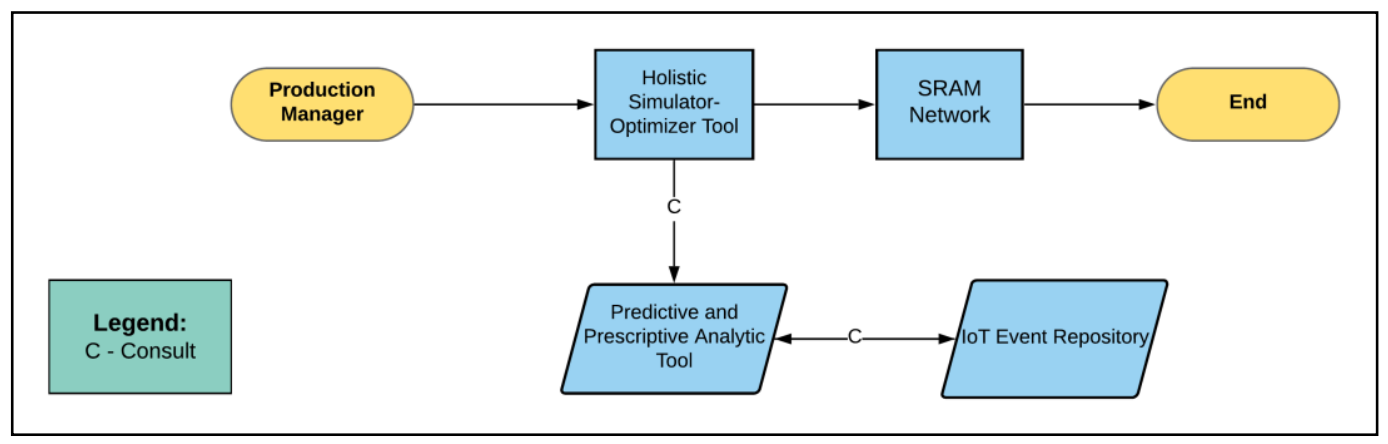

Source: the authors

Using all the gathered data from the FASTEN loT Event Repository, the FASTEN Predictive and Prescriptive Analytic Tool analyses the demand including seasonal patterns, thus providing information about future demands and suggesting which are the best cities to operate a SRAM unit. This process is started by Production Manager (PM) who runs the FASTEN Holistic Simulator-Optimizer tool. This toll provides data regarding the number of SRAM units needed, where these SRAM's will be located, and how many 3D printers will be installed at each SRAM unit. After the configuration of the SRAM Network, the FASTEN IOT Platform is ready to be used.

To test the functionalities of the FASTEN IOT Platform, an industrial experiment was conducted to simulate the full operation of an equipment maintenance. The process starts when the client reports a product's malfunction or broken part through his mobile App. At the client, the Maintenance Team (MT) reviews the equipment and orders, if necessary, new parts to replace worn or broken ones. The MT also uses a mobile APP to order spare parts, which is connected to the company's ERP. After the MT publishes a spare part request, the full manufacture process is managed by the company's ERP. After the order is published at the ERP system, it will check if the part is available at any warehouse or if it needs 
to be manufactured. The warehouses used by FASTEN are Smart Warehouses - in other words, warehouses that employ Cyber Physical Systems to automate operations of pickup, delivery or bookkeeping, resulting in an automated, unmanned and paperless warehouse (Liu et al. 2018). Such warehouses have all their stock controlled by an automated system. When the part is available at a warehouse, it is shipped to the MT as soon as possible. If the part is not available, the ERP sends a Manufacturing order to the FASTEN IoT Platform.

The manufacturing process starts through an optimization request to the FASTEN Holistic Simulator-Optimizator tool. This request is necessary as the Holistic Optimization-Simulation tool will inform which SRAM unit is available (considering the type of part, type of client, SRAM availability, lead-time, cost, capacity, maximum number of 3D printers in a SRAM, time of producing the spare part, cost of acquiring the same spare part from an External Supplier (ES), suppliers' delivery time to the warehouse, suppliers' delivery costs and internal order cost to produce that part. After concluding the analysis, the FASTEN SimulationOptimization tool informs the ERP to which SRAM the order should be sent.

In the functional test, the client was located in Rio de Janeiro, and the system decided to produce the part in Salvador. The ERP then informs the Advanced Plant Model (APM) responsible for the SRAM assigned, who is responsible for allocating the manufacturing order to the specific 3D printer and to the robot, after the part is printed. This order arrives directly in the SRAM that will then start printing the requested spare part. While the SRAM is producing the order, the Real-Time Monitoring and Performance Management Tool (Dashboard) presents real-time data coming from the $3 \mathrm{D}$ printer, also the ERP monitors the loT Event Repository to know when the SRAM becomes idle.

Once the printing process is finished, the $3 \mathrm{D}$ printer sends the status to the APM, who then assigns the picking order to the robot. The robot will pick the printed spare part up from the 3D printer autonomously and place it at the SRAM shipping area for Dispatch Manager/Logistics. The last step is concluded when the MT receives the spare part and installs in the machine, closing the service.

\section{Face Shield AM Network}

The flexibility of the FASTEN platform allowed us to identify different situations for its application. With the Covid-19 pandemic in Brazil, we suffered from supply problems and some supply chains had to restructure. One case is the face shield supply chain for healthcare professionals. 
The Covid-19 pandemic in Brazil ended up demanding Education and Research Institutions to support health professionals and institutions. Many 3D printing centers started to produce face shields and some of them started to structure themselves as focal centers in supply chains, managing the demands and distribution of inputs and raw materials to other printing centers. The FASTEN platform will allow the structuring, management and operation of this network.

The FASTEN platform is being adapted for demand and production management in an AM center in an educational and research institution. This institution implemented actions to help combat the spread of the virus. One of them is the production of face shields in a laboratory equipped with eight 3D printers.

The production serves 45 health institutions and hospitals so far, and more than 4000 face shields have already been delivered. In order to meet demand, the strategy was to seek local partners interested in sharing their AM productive capacity as an additive manufacturer. Partners may connect printers to the Laboratory's AM center through the Internet, being available to receive demands managed by the Center. Parts printed at partners (mostly located at the University's technology park) are sent to the AM Center where the assembly is completed, and the delivery is made. The AM network is composed of 8 equipment from AM center and 7 equipment from partners, being each equipment considered a SRAM.

Currently, management is manual and centralized in a print center manager. The demand is still subject to approval by AM Center managers. With the demand approved, the production order is sent for allocation to the available printers. The loading on the printers is defined by the professionals who operate the printers.

The AM network should improve production efficiency, through: (i) digitizing the product life cycle management process; (ii) the interconnection between internal and external supply chain processes; and (iii) the implementation of flexible production planning, scheduling and optimization processes to meet a wide range of products (Blanchet et al. 2014; Lasi et al., 2014). The FASTEN platform supports all these requirements: interoperability, decentralization and virtualization.

Interoperability allows the connection between systems of different production processes, internal or external to the focal production unit (Ideia). Decentralization is based on the autonomy of decision making by FASTEN platform. The management of productive capacity is made by collecting and analyzing data in real time, allowing reactions to machine failures or redirecting production paths. 
We are working on preparing each SRAM, as they must implement and/or connect with an autonomous manufacturing system for the production of products with personalized design on 3D printers: an open source industrial loT Platform for product manufacturing and process control. The preparation of production units, to act in the supply network, is a critical point in the process of development of suppliers and their integration.

The preparation of the tests is in progress and a significant gain is expected: (i) in time to meet the demand, as the decision-making times regarding the loading of the equipment will be reduced; (ii) the traceability of demand and production data and information; and (iii) in real time control of the SRAM.

\section{Concluding Comments}

This paper has addressed a research-practice nexus about the implementation and operation of a Smart Manufacturing System, a system well-suited to the uncertainties and disruptions of a pandemic. The application of FASTEN platform for management of an AM network allows the interconnection of $3 \mathrm{D}$ printers available in any location with internet access. The development of AM centers addresses the main objective of AM - flexibility and customization - expanding the availability of these equipment in Covid-19 pandemic conditions. With these conditions, many countries worldwide are suffering from lack of supplies since lockouts have constrained manufacturing and transportation. An AM center may manage printers located in different regions, improving the availability of safety equipment for healthcare teams. In the (inter)organizational environment, it will allow the identification of existing interdependencies and potential supply disruption risks. In addition, the system will make it possible to identify and/or predict the consequences and operational and financial impacts of supply disruption risks due to the use of simulation tools for the analysis of mitigation actions and strategies.

Disruptions in the flows of production, movement and transportation of materials, financial flows and information flows, require greater information sharing, coordination and collaboration between participants, to ensure the continuity of operations. The FASTEN makes it possible to deal with uncertainties and vulnerabilities, both preventively and reactively, providing robustness and/or resilience in the SC, for the absorption of irregularities or supply failures, or supporting, with agility, the reaction to the effects of the risks of rupture.

Additionally, the study highlights the importance that the supply chain information flows have in improving SC performance. The number of 
supply chain research articles published over the last 10 years has grown exponentially. Studies that address analysis of mitigation and contingency strategies and impacts on SC performance, resilience and/or robustness are suggested by several literature review studies (e.g., Hohenstein et al. 2015; Tukamuhabwa et al. 2015; Ho et al. 2015; Bandaly et al. 2013; Ghadge, Dani and Kalawsky 2012; Simangunsong, Hendry, and Stevenson 2012; Sodhi, Son and Tang 2012; Wilding et al. 2012) There is also a lack of practical studies about the impact of disruptive risk incident on the rupture and resilience of a supply chain (Chopra and Sodhi 2014), especially in an emerging country (Shao 2013).

The FASTEN platform will allow the structuring, management and operation of a SC in supply disruption risk incident, based on real-time connection between demanding systems and supplier systems. SMS systems are changing the behavior of the industry, mainly in relation to production planning and control practices in companies and throughout the supply chain.

In Brazil, there continue to be many difficulties to implement technologies of Industry 4.0, due to the associated costs and investments. There is no one-size-fits-all strategy that suits all businesses or industries or countries. The Industry 4.0 roadmap for each company is idiosyncratic, and should be devised based on the company's core competencies, motivations, capabilities, intent, goals, priorities and budgets (Ghobakhloo 2018). The impact of the fourth industrial revolution on SC can be considered largely positive, especially if the authorities, governmental agencies and international associations - following the lessons learned from the pandemic - assist and facilitate the process of digital transformation. 


\section{References}

Bandaly, Dia, Latha Shanker, Yasemin Kahyaoglu and Ahmet Satir (2013), "Supply Chain Risk Management-II: A Review of Operational, Financial and Integrated Approaches," Risk Management, 15 (1), 1-31. https://doi.org/10.1057/rm.2012.8

Barata, João, Paulo Rupino Da Cunha and Janusz Stal (2018), "Mobile Supply Chain Management in the Industry 4.0 Era," Journal of Enterprise Information Management, 31 (1), 173-92. https:///doi/10.1108/JEIM-09-2016-0156

Blanchet, Max, Thomas Rinn, Georg Von Thaden, and G D Thieulloy (2014), "Think Act INDUSTRY 4.0 The New Industrial Revolution How Europe Will Succeed," Munich: Roland Berger Strategy Consultants. (accessed on September 2, 2019), [available at: http://www.iberglobal.com/files/Roland Berger Industry.pdf]

Bonomi, Flavio, Rodolfo Milito, Jiang Zhu, and Sateesh Addepalli (2012), "Fog Computing and Its Role in the Internet of Things," In Proceedings of the First Edition of the MCC Workshop on Mobile Cloud Computing - MCC '12, New York, New York, USA: ACM Press, 13. (accessed on September 2, 2019), [available at: http://dl.acm.org/citation.cfm?doid=2342509.2342513]

Brecher, Christian, Christian Ecker, Werner Herfs, Markus Obdenbusch, Sabina Jeschke, Max Hoffmann, Tobisas Meisen (2017), "The Need of Dynamic and Adaptive Data Models for Cyber-Physical Production Systems," In Cyber-Physical Systems, Elsevier, 32138.

Brettel, Malte, Niklas Friederichsen, Michael Keller and Marius Rosenberg (2014). "How Virtualization, Decentralization and Network Building Change the Manufacturing Landscape: An Industry 4.0 Perspective," International Journal of Mechanical, Aerospace, Industrial and Mechatronics Engineering, 8 (1), 37-44. doi.org/10.5281/zenodo.1336426

Büyüközkan, Gülçin and Fethullah Göçer (2018), "Digital Supply Chain: Literature Review and a Proposed Framework for Future Research," Computers in Industry, 97, 157-77. https://doi.org/10.1016/i.compind.2018.02.010 
Carvalho, Helena, Susana, Garrido Azevedo and V. Cruz-Machado (2012), "Agile and Resilient Approaches to Supply Chain Management: Influence on Performance and Competitiveness," Logistic Research, 1 (2), 49-62. https://doi.org/10.1007/s12159$\underline{012-0064-2}$

Chopra, Sunil, and M. S. Sodhi (2004), "Supply-Chain Breakdown," MIT Sloan Management Review, 46 (1), 53-61.

and Manmohan Sodhi (2014), "Reducing the Risk of Supply Chain Disruptions," MIT Sloan Management Review, 55 (3): 72-80.

European Comission (2016), "Final Paper on a Strategic Approach to EU Agricultural Research and Innovation - European Commission," European Commission, (accessed on November 20, 2018), [available

at: https://ec.europa.eu/programmes/horizon2020/en/news/final-paperstrategic-approach-eu-agricultural-research-and-innovation]

Dalmarco, Gustavo, Filipa R. Ramalho, Ana C. Barros and Antonio L. Soares (2019), "Providing Industry 4.0 Technologies: The Case of a Production Technology Cluster," The Journal of High Technology Management Research, 30 https://doi.org/10.1016/j.hitech.2019.100355

Davis, Jim, Thomas Edgar, James Porter, John Bernadend, Michael Sarlie (2012), "Smart Manufacturing, Manufacturing Intelligence and Demand-Dynamic Performance," Computers and Chemical Engineering, $\quad 47 \quad$ (20), 145-56. https://doi.org/10.1016/i.compchemeng.2012.06.037

Evans, Peter C. and Marco Annunziata (2012), "Pushing the Boundaries of Minds and Machines," Ge, (accessed on September 2, 2019), [available https://www.ge.com/docs/chapters/Industrial Internet.pdf]

Garcia-Herreros, Pablo, John M. Wassick and Ignacio E. Grossmann (2014), "Design of Resilient Supply Chains with Risk of Facility Disruptions," Industrial and Engineering Chemistry Research, 53 (44), 17240-51. https://doi/org/10.1016/j.tre.2017.02.004

Ghadge, Abhijeet, Samir Dani and Roy Kalawsky (2012), "Supply Chain Risk Management: Present and Future Scope," The International Journal of Logistics Management, 23 (3), 313-39. https://doi.org/10.1108/09574091211289200 
Ghobakhloo, Morteza (2018), "The Future of Manufacturing Industry: A Strategic Roadmap toward Industry 4.0," Journal of Manufacturing Technology Management, 29 (6), 910-36. https://doi.org/10.1108/JMTM-02-2018-0057

Gubbi, Jayavardhana, Rajkumar Buyya, Slaven Marusic and Marimuthu Palaniswami (2013), "Internet of Things (IoT): A Vision, Architectural Elements, and Future Directions," Future Generation $\begin{array}{llll}\text { Computer Systems, } & 29 & \text { (7), } & \text { 1645-60. }\end{array}$ https://doi.org/10.1016/j.future.2013.01.010

Ho, William, Tian Zheng, Hakan Yildiz and Srinivas Talluri (2015), "Supply Chain Risk Management: A Literature Review," International Journal of Production Research, 53 (16), 5031-69. https://doi.org/10.1080/00207543.2015.1030467

Hohenstein, Nils Ole, Edda Feise, Evi Hartmann and Larry Giunipero (2015), "Research on the Phenomenon of Supply Chain Resilience: A Systematic Review and Paths for Further Investigation," International Journal of Physical Distribution and Logistics Management, 45, 90-117. https://doi.org/10.1108/IJPDLM-052013-0128

Huang, Yong, Ming C. Leu, Jyoti Mazumder and Alkan Donmez (2015), "Additive Manufacturing: Current State, Future Potential, Gaps and Needs, and Recommendations," Journal of Manufacturing Science and Engineering, Transactions of the ASME 137 (1). https://doi/org/10.1115/1.4028725

Jared, Bradley H., Miguel A.Aguilo, Lauren L. Beghini, Brad L.Boyce, Brett W. Clark, Adam Cook, Bryan J. Kaehr, Joshua Robbins (2017), "Additive Manufacturing: Toward Holistic Design," Scripta Materialia, 135, 141-47. https://doi.org/10.1016/i.scriptamat.2017.02.029

Kleindorfer, Paul R. and Germaine H. Saad (2005), "Managing Disruption Risks in Supply Chains," Production and Operations Management, 14 (1), 53-68. https://doi/org/10.1111/j.1937-5956.2005.tb00009.x

Kumar, Arun and Satyam Kumar (2020), "Industry 4.0: Evolution, Opportunities and Challenges," International Journal of Research in Business Studies, 5 (1), 139-148.

Lasi, Heiner, Peter Fettke, Thomas Feld, Michael Hoffmann (2014), "Industry 4.0," Business and Information Systems Engineering, 6 (4), 239-42. https://doi.org/10.1007/s12599-014-0334-4 
Leung, Daniel, Ada Lo, Lawrence Hoc Nang Fong and Rob Law (2015), "Applying the Technology-Organization-Environment Framework to Explore ICT Initial and Continued Adoption: An Exploratory Study of an Independent Hotel in Hong Kong," Tourism Recreation Research, $40 \quad$ (3), 391-406. https://doi.org/10.1080/02508281.2015.1090152

Lin, Danping, C. K.M. Lee, Henry Lau and Yang Yang (2018), "Strategic Response to Industry 4.0: An Empirical Investigation on the Chinese Automotive Industry," Industrial Management and Data Systems, 118 (3), 589-605. https://doi.org/10.1108/IMDS-09-2017$\underline{0403}$

La Mora, Roberto (2014), "Cisco IOx: An Application Enablement Framework for the Internet of Things - Cisco Blog," Cisco Blog Digital Transformation," Cisco, (accessed on September 2, 2019), [available at: https://blogs.cisco.com/digital/cisco-iox-an-applicationenablement-framework-for-the-internet-of-things]

Osakwe, Christian Nedu, Miloslava Chovancová and Monica Agu (2016), "Can Micro-Enterprises Leverage on the Adoption of Corporate Websites to Bolster Their Brand Visibility? Examining Salient Adoption Issues in Nigeria," Information Development, 32 (4), 90419. https://doi.org/10.1177/0266666915573551

Oztemel, Ercan and Samet Gursev (2020), "Literature Review of Industry 4.0 and Related Technologies," Journal of Intelligent Manufacturing, 31 https://doi.org/10.1016/.icte.2018.01.016

(1), 127-82.

Ponomarov, Serhiy Y. and Mary C. Holcomb (2009), "Understanding the Concept of Supply Chain Resilience," The International Journal of Logistics Management, 20 https://doi.org/10.1108/09574090910954873

(1), 124-43.

Porter, Michael, and James Heppelmann (2015), "Como Produtos Inteligentes e Conectados Estão Transformando Empresas," Harvard Business Review, (accessed on September 23, 2019), [available at: https://hbr.org/2015/10/how-smart-connectedproducts-are-transforming-companies] 
Reis, Ricardo et al. (2018),"FASTEN: An loT Platform for Manufacturing. Embraer Use Case," MATEC Web of Conferences 233: 00009, (accessed on June 29, 2019), [available at: https://www.matecconferences.org/articles/matecconf/abs/2018/92/matecconf easn c eas2018 00009/matecconf easn ceas2018 00009.html]

Rübmann, $M$ et al. (2015), "Industry 4.0: The Future of Productivity and Growth in Manufacturing Industry," Report by Boston Consulting Group (BCG), (accessed on September 12, 2019), [available at: https://image-

src.bcg.com/Images/Industry 40 Future of Productivity April 201 5 tcm9-61694.pdf]

Sabri, Ehap H. and Benita M. Beamon (2000), "A Multi-Objective Approach to Simultaneous Strategic and Operational Planning in Supply Chain Design," Omega, 28 (5), 581-98. https://doi.org/10.1016/S0305-0483(99)00080-8

Shao, Xiao-Feng (2013), "Supply Chain Characteristics and Disruption Mitigation Capability: An Empirical Investigation in China," International Journal of Logistics Research and Applications, 16 (4), 277-95. https://doi.org/10.1080/13675567.2013.815695

Sheffi, Yossi, and James B Rice (2005), "A Supply Chain View of the Resilient Enterprise," MIT Sloan Management Review, 47 (1), 41.

Simangunsong, Eliot, Linda C Hendry and Mark Stevenson (2012), "Supply-Chain Uncertainty: A Review and Theoretical Foundation for Future Research," International Journal of Production Research, 50 (16), 4493-4523. https://doi.org/10.1080/00207543.2011.613864

Sodhi, ManMohan S, Byung-Gak Son and Christopher S Tang (2012), "Researchers' Perspectives on Supply Chain Risk Management," Production and Operations Management, 21 (1), 1-13. https://doi.org/10.1111/j.1937-5956.2011.01251.x

Tang, Christopher S. (2006), "Perspectives in Supply Chain Risk Management," International Journal of Production Economics, 103 (2), 451-88. https://doi.org/10.1016/j.ijpe.2005.12.006Get

Tang, Ou and S. Nurmaya Musa (2011), "Identifying Risk Issues and Research Advancements in Supply Chain Risk Management," International Journal of Production Economics, 133 (1), 25-34. https://doi.org/10.1016/j.ijpe.2010.06.013 
Thun, Jörn Henrik and Daniel Hoenig (2011), "An Empirical Analysis of Supply Chain Risk Management in the German Automotive Industry," International Journal of Production Economics, 131 (1), 242-49. https://doi.org/10.1016/j.ijpe.2009.10.010

Tukamuhabwa, Benjamin R, Mark Stevenson, Jerry Busby and Marta Zorzini (2015), "Supply Chain Resilience: Definition, Review and Theoretical Foundations for Further Study," International Journal of Production Research, 53 (18), 5592-5623. https://doi.org/10.1080/00207543.2015.1037934

Vicdan, Handan (2020), "Platformization of COVID and the Rise of Biosocial Surveillance," Markets, Globalization \& Development Review, 5 (3), Article 2. https://doi.org/10.23860/MGDR-2020-0503-02

Wagner, Stephan M. and Christoph Bode (2008), "An Empirical Examination Of Supply Chain Performance Along Several Dimensions Of Risk," Journal of Business Logistics, 29 (1), 307-25. https://doi.org/full/10.1002/j.2158-1592.2008.tb00081.x

Wilding, Richard, Beverly Wagner, Claudia Colicchia and Fernanda Strozzi (2012), "Supply Chain Risk Management: A New Methodology for a Systematic Literature Review," Supply Chain Management, $17 \quad$ (4) 401-418. https://doi.org/10.1108/13598541211246558 